\title{
ANGGOTA TUBUH TERKHITBAH YANG BOLEH DI PANDANG MENURUT IBNU HADZM
}

\author{
Muhammad Alwin Abdillah \\ Dosen Fakultas Syariah IAIN Langsa \\ Rasyidin \\ rasyidin83iainlangsa@gmail.com \\ Dosen Fakultas Syariah IAIN Langsa
}

\begin{abstract}
To reach an ideal household (mawaddah warohmah), various preparatory efforts are needed as early as possible to support the marriage. This preparation must have started since the introduction process until there is a determination to get to the marriage level. Broadly speaking, preparations that must be required include a prospective husband and wife must be ready or mature physically, mentally (psychologically), socially and sexually. Khitbah in Indonesian is the same as engagement, engagement or proposal. The word "khitbah" comes from Arabic which is a masdar form of the word خطب which means to propose or propose. In the Indonesian Islamic Encyclopedia explained that Khitbah means the proposal or proposal, which is the proposal of a man who wants to marry a woman, whether she is still a girl or already a widow. In this case proposal can be done by men and women in accordance with the customs that apply to the community or the environment they live. Ibn Hazm has his own minhaj (method) in understanding texts, that is, the Zhahiri minhaj which is very different from the school of worship that is adopted by jumhur. In understanding a text Ibn Hazm took directly from the provisions of the text al-Qur'an and the hadith, he only looked at what they can see from the outside only. Not proclaiming the law, not searching for 'illat, he even said that the text must be understood in its final way. Ibn Hazm argues that when preaching a man can see the whole body of his future wife without exception. Whether it's aurat or not.
\end{abstract}

Keyword: Engagement, Islamic Law

\section{Pendahuluan}

Keadaan sebuah lembaga pernikahan yang sah merupakan landasan utama bagi masyarakat demi terbentuknya sebuah keluarga yang sakinah, karena keluarga merupakan embrio dari kehidupan yang terkecil dari komunitas masyarakat. Proses pembentukan keluarga melalui sebuah lembaga pernikahan yang sah pada dasarnya merupakan satu hal yang telah disyariatkan dalam al- Quran. ${ }^{1}$

Untuk mencapai sebuah rumah tangga yang ideal (mawaddah warohmah), sedini mungkin perlu adanya berbagai macam upaya persiapan untuk mendukung terlaksananya pernikahan. Persiapan ini harus sudah dimulai sejak proses perkenalan hingga ada ketetapan hati untuk menuju ke

\footnotetext{
${ }^{1}$ Ahmad Kuseri, Nikah Sebagai Perikatan,
} Jakarta: Raja Grafindo Persada, 1995, hlm. 26. 
jenjang pernikahan. Secara garis besar persiapan yang harus dibutuhkan antara lain calon suami istri harus siap atau matang secara fisik, mental (psikologis), sosial dan seksual.

Dalam hal ini yang perlu diperhatikan antara lain adalah mempersiapkan kematangan alat-alat reproduksi, rasa tanggung jawab baik secara materi maupun mental serta kesiapan untuk hidup di tengah-tengah masyarakat yang plural.

Seiring dengan persiapan yang dibutuhkan sebelum pernikahan maka yang tidak kalah pentingnya adalah proses pengenalan pribadi masingmasing, baik dari segi sifatnya, karakter individu, agamanya, kehormatannya maupun bentuk fisiknya. Hal ini sangat dibutuhkan agar dalam mengarungi bahtera rumah tangga tidak muncul sebuah penyesalan yang timbul dari sesuatu yang sebelumnya disembunyikan.

Langkah selanjutnya yang diambil setelah mengetahui pribadi masing- masing adalah melakukan khitbah atau meminang. Meminang maksudnya seorang laki-laki meminta kepada seorang perempuan untuk menjadi istrinya, dengan cara-cara yang sudah umum berlaku ditengah-tengah masyarakat.

Khitbah dalam bahasa Indonesia sama artinya dengan peminangan, pertunangan atau lamaran. Kata "khitbah" ini berasal dari bahasa arab yang merupakan bentuk masdar dari kata خطب yang berarti meminang atau melamar.3 Dalam Ensiklopedi Islam Indonesia dijelaskan bahwa Khitbah artinya lamaran atau pinangan, yaitu lamaran seorang laki-laki yang hendak memperistri seorang perempuan, baik perempuan itu masih gadis atau sudah janda. Dalam hal ini pinangan bisa dilakukan oleh pihak lakilaki maupun wanita sesuai dengan adat yang berlaku pada masyarakat atau lingkungan mereka tinggal.

\section{Mengenal Ibnu Hadz adz - Dzahiri}

Nama lengkap Ibnu Hazm adalah Ali Ibnu Ahmad Ibnu Said Ibnu Hazm Ibnu Ghalib Ibnu Shalih Ibnu Khalaf Ibnu Ma'dan Ibnu Sufyan Ibnu Sufyan. Ia dilahirkan hari Rabu pada tanggal 7 November 994 M bertepatan dengan hari akhir bulan Ramadhan 384 H, yaitu pada waktu sesudah terbit fajar sebelum munculnya matahari pagi Idul Fitri di Cordova, Spanyol. $^{2}$

Banyak ulama klasik dan kontemporer memakai nama singkatnya dengan sebutan Ibnu Hazm dan terkadang dihubungkan dengan panggilan al- Qurthubi atau alAndalusi yang dinisbatkan pada tempat kelahirannya, Cordova dan Andalus. Kadang Ia dikenal dengan sebutan alZahiri sehubungan dengan aliran fiqh dan pola fikir al-Zahiri yang dianutnya.

Kakek Ibnu Hazm beserta keluarga Bani Umayyah pindah ke Andalusia, sementara keluarga Bani Hazm tinggal di Manta Lisyam, kota kecil yang menjadi pemukiman orang Arab di Andalusia. Di sana mereka hidup dengan kemewahan dan kedudukan terhormat. Oleh karena itu IbnuHazm dan keluarganya memihak Bani Umayyah. $^{3}$

Ayah Ibnu Hazm bernama Ahmad Ibnu Said berpendidikan cukup tinggi, ia menjadi pejabat di lingkungan kerajaan

\footnotetext{
${ }^{2}$ Rahman Alwi, Metode Ijtihad Mazhab al-Zahiri Alternatif Menyongsong Modernitas, (Jakarta: Gaung Persada Press, 2005), cet. ke-1 h. 29

${ }^{3}$ Ibid.,
} 
Khalifah Abu Amir Muhammad IbnuAbi Amir (Al-Mansur) dan kemudian menjadi wazir (menteri) al-Mansur pada tahun 381 H/991 M. Ia tinggal bersama keluarganya di Muniyyat al-Mughirat, pemukiman pejabat istana di bagian Timur Cordova dekat istana al-Zahirat, pusat kerajaan alMansur. Ia juga sempat menjabat wazir di masa pemerintahan al-Muzaffar yang wafat pada tahun $402 \mathrm{H}^{4}$

\section{Pendidikan dan Guru-Guru Ibnu Hazm}

Pada masa kecilnya, Ibnu Hazm diasuh oleh wanita-wanita istana. Ia dibimbing dan diasuh oleh guru-guru wanita yang mengajarkannya membaca dan menghafal al-Qur'an, syair dan melatihnya menulis.Di saat usianya menginjak remaja, ia diajak oleh ayahnya menghadiri majelis-majelis ilmiah dan budaya yang sering diadakan khalifah alMansur dan dihadiri pula oleh ahli-ahli syair dan ilmuwan. Ia juga belajar kepada seorang guru yang alim dan wara' yaitu Abu al-Husain Ibnu Ali al-Farisi. Ibnu Hazm selalu disamping guru pilihan ayahnya itu, seorang guru yang melenyapkan dorongan-dorongan nafsu diri murid muda seperti Ibnu Hazm. Ketika itu wanita tidak berhijab di depan kaum pria, menurut Ibnu Hazm adalah merupakan hal yang biasa di dalam dunia pendidikan di Andalusia. Dengan kecepatan daya tangkap, kekuatan daya ingat dan kecermatan pemahamannya, Ibnu Hazm menjadi pemuda yang nyaris mengungguli guru-gurunya. ${ }^{5}$

Guru Ibnu Hazm lainnya adalah Abu al-Qasim Abd al-Rahman Ibnu Abi Yazid al-Misri (wafat tahun $410 \mathrm{H}$ ). Ibnu Hazm diajak untuk menghadiri majelis untuk belajar ilmu hadits dan sastra Arab.

Ilmu yang mula-mula dipelajari oleh Ibnu Hazm adalah ilmu hadits setelah ia menghafal al-Quran dan ilmu sya'ir bahasa Arab. Ilmu hadis juga dipelajarinya dari alHamazani dan Abu Bakar Muhammad ibnu Ishaq. ${ }^{6}$

Ilmu fiqh pertama kali diperoleh dari fiqh mazhab Maliki, karena mazhab ini yang banyak dianut oleh masyarakat Andalusia. Bahkan bisa dikatakan mazhab Maliki adalah mazhab resmi negara. Diriwayatkan bahwa Ibnu Hazm pernah berkata bahwa di masanya ada dua mazhab yang tersebar karena didukung oleh penguasa negeri, yaitu mazhab Abu Hanifah di Timur (wilayah Irak dan sekitarnya) dan mazhab Maliki di Barat (Spanyol dan sekitarnya). ${ }^{7}$

Faktor mengapa Ibnu Hazm mendalami ilmu fiqh dijelaskan seperti yang diriwayatkan dari Abu Muhammad Ibnual-'Arabi, yaitu ketika Ibnu Hazm datang ke masjid untuk shalat jenazah bagi seorang pembesar saudara ayahnya, ia langsung duduk tanpa shalat tahiyyat masjid, guru pembimbingnya memberi isyarat untuk bangkit berdiri dan shalat tahiyyat masjid namun Ibnu Hazm tidak melakukannya. Banyak orang di sekitarnya berkata (seakan mengejek), Sudah sedewasa ini usiamu namun kamu belum mengerti bahwa shalat tahiyyat masjid itu wajib. Usianya kala itu 26 tahun. Ibnu Hazam berkata, Lalu aku bangkit dan mengerjakan Salat tahiyyat masjid, aku baru paham isyarat guruku tadi. ${ }^{8}$

Ibnu Hazm juga banyak menimba ilmu dari ulama-ulama berpengaruh di masanya, seperti Ibnu Abdulal-Barr al-Maliki dan

\footnotetext{
${ }^{6}$ Rahman Alwi, op.cit., h. 32-33

${ }^{7}$ Ibid.,

${ }^{8}$ Ibid.,h. 35
} 
Abdullah al-Azdi (wafat tahun $403 \mathrm{H}$ ) yang dikenal dengan sebutan Ibnu al-Fardhli, seorang qadi Valencia. Ia mempelajari ilmu fiqh dan hadits darinya. Di samping ahli dalam bidang fiqh dan hadis, Ibnu alFardhli juga ahli dalam bidang sastra dan sejarah, khususnya tentang biografi para ulama' Andalusia. Ibnu al-Fardhli wafat dibunuh oleh tentara Barbar tahun $403 \mathrm{H}^{9}{ }^{9}$ Guru Ibnu Hazm lainnya adalah Muhammad Ibnu al-Hasan al-Mazhaji yang lebih dikenal dengan nama Ibnu al-Katani dan juga Ahmad Ibnu Muhammad Ibnu Abdul Waris. Dari gurunya tersebut Ibnu Hazm mempelajari ilmumantiq (logika) dan filsafat ${ }^{10}$.

Pencarian Ibnu Hazm akan ilmu tidak selesai saja pada mazhab Maliki, ia melanjutkan pendalaman fiqh mazhab Syafi'i yang kurang populer di Andalusia. Ibnu Hazm mempelajari fiqh Syafi'i secara otodidak, juga ilmu muqaran (fiqh perbandingan), tafsir dan hadits dari kitabkitab karya ulama' yang amat tinggi nilainya, misalnya kitab tafsir karya Baqi Ibnu Makhlad dan kitab Ahkam al-Qur'an karya Ibn Umayyah al-Hijazi, ulama' yang bermazhab Syafi'i, serta kitab tafsir karya seorang ulama' pembela mazhab alDawudi (al-Zahiri) Abu al-Hakam Munzir ibn Sai'd. ${ }^{10}$

Di Madrasah Andalusiyyah Ibnu Hazm belajar fiqh dengan metode pembahasan yang berpedoman pada atsar (riwayat sahabat) dalam berijtihad. Tokoh-tokoh yang mengajar di madrasah tersebut banyak menulis buku- buku yang berharga dan berpengaruh bagi pemikiran Ibnu Hazm seperti kitab-kitab di bidang hadits, ahkam al-Qur'an, tarikh dan fiqh karya
Qasim bin Asbagh al- Qurthubi, Ahmad Ibnu Khalid dan Muhammad Ibnu Aiman. ${ }^{11}$

Ada seorang guru yang sangat berpengaruh terhadap pemikiran Ibnu Hazm yaitu Mas'ud Ibnu Sulaiman Ibnu Muflit Abu al-Khiyar (wafat tahun $426 \mathrm{H}$ ), seorang ulama' ahli fiqh muqaran yang bermazhab al-Zahiri. Gurunya ini cenderung mengambil arti zahir dari nash dan mempunyai daya pilih di antara berbagai mazhab. Yang menarik adalah sikapnya yang bebas untuk berpikir dan tidak terikat dengan mazhab tertentu. Dari pergaulan dengan gurunya ini Ibnu Hazm sampai pada suatu pendirian sehingga ia berkata, aku mengikuti kebenaran, aku berijtihad dan aku tidak terikat oleh mazhab. ${ }^{12}$

Dibekali dengan ilmu yang makin luas, serta karunia intlektualitasyang tinggi ditambah dengan kondisinya yang selalu berpindah-pindah dan dimanfaatkan untuk mengembara mencari ilmu, Ibnu Hazm banyak melakukan perdebatan-perdebatan dengan ulama-ulama di masanya. Ia tidak hanya dikenal sebagi seorang muhaddits dan faqih saja, namun ia juga ahli dalam berbagai bidang, seperti ushul fiqh, sastra Arab, sejarah, mantiq, filsafat, ilmu kalam dan ilmu perbandingan agama.

Di samping itu suasana keilmuan pada masa Ibnu Hazm sangat mendukung dalam pencariannya akan ilmu pengetahuan, seperti perpustakaan dan universitas Cordoba yang berkembang pesat serta di Toledo (Spanyol) menjadi pusat kegiatan penerjemahan ilmu-ilmu Yunani, baik filsafat, matematika dan kedokteran. ${ }^{13}$

Ibnu Hazm adalah pengembang
${ }^{9}$ Ibid.,
${ }^{10}$ Ibid.,h. 37.
${ }^{13}$ Ibid.,h. 39.
${ }^{11}$ Ibid.,
${ }^{12}$ Ibid.,


mazhab al-Zahiri ${ }^{14}$, bahkan ia dinilai sebagai pendiri kedua setelah Daud alZahiri. Ketika Ibnu Hazm menginjak remaja yaitu dalam usia lima belas tahun, terjadi pemberontakan yang melibatkan ayah Ibnu Hazm, setelah terjadi kekacauan yang terjadi lantaran perebutan kekuasaan, ayah Ibnu Hazm meninggalkan lapangan politik serta pindah dari bagian Timur Cordova ke bagian baratnya, kemudian wafat di sana pada tahun $402 \mathrm{H}^{15}$

Dalam bidang politik, Ibn Hazm pernah menjadi pemimpin pasukan di Granada dan berkali-kali diangkat menjadi wazir pada masa dinasti Bani Umayyah. ${ }^{16}$

Pada tahun 399 H, Ibnu Hazm dan keluarganya terpaksa harus terusir dari istananya di Cordova. Saat itu terjadi pertempuran sengit untuk merebut kekuasaan (kudeta) dari tangan penguasa oleh pemberontak yang didukung pasukan nasrani dari Eropa. Keluarga Ibnu Hazm mengalami kesukaran- kesukaran, selalu berpindah-pindah tempat, ia sering mengalami pengasingan dan dalam kesulitan hidup, kepindahankepindahannya dari kota ke kota kadangkadang dengan jalan paksaan dan kadang untuk mencari ketenangan ia ingin melihat wajah tenpat kelahirannya. ${ }^{17}$ Ibnu hazm menggambarkan dirinya dan masyarakat Andalusia saat itu diliputi dengan kegelisahan, ketakutan, mereka pun kehilangan mata pencaharian, tidak ada hukum yang jelas. Menurutnya satu-

\footnotetext{
${ }^{14}$ Ibid.,

${ }^{15}$ Hasbi al-Siddiqi, Pokok-pokok Pegangan Imam-imam Mazhab dalam Membina Hukum Islam, (Jakarta: Bulan Bintang, 1974), cet. ke-4, h. 556

${ }^{16}$ Rahman Alwi,op.cit., h.40

${ }^{17}$ Dewan Redaksi Ensiklopedia Islam, Ensiklopedia Islam, (Jakarta: Ichtiar Baru Van Hoeve, 1994), cet. ke-3 h. 149.
}

satunya cara untuk mengatasi dan menghilangkan hal itu semua adalah kembali kepada hukum Tuhan. $^{18}$ Ibnu Hazm pernah berdiam disuatu pulau mengepalai jama'ah ditempat itu, di pulau itu iamendapat kebebasan untuk berdiskusi, untuk mengembangkan pikiran dan pendapat- pendapatnya.

Ia berkiprah dalam kancah politik hingga tahun $422 \mathrm{H}$ setelah berakhirnya kekuasaan dinasti Bani Umayyah di Andalusia. ${ }^{19}$ Kondisi sosial politik yang dialaminya telah membentuk karakter Ibnu Hazm menjadi sangat keras. Ia sering dikucilkan oleh ulama-ulama semasanya karena pemikirannyadan kritik-kritik tajamnya. al-Maraghi pernah mencatat bahwa yang mau belajar dengan Ibnu Hazm adalah orang-orang yang berani menanggung resiko senasib dengan Ibnu Hazm sendiri.Akan tetapi diceritakan oleh al-Zirikli bahwa Ibnu Hazm sempat juga menghasilkan sekelompok ulama' yang menamakan diri mereka al-Hazmiyyah (para pengikut Ibnu Hazm) di Spanyol. ${ }^{20}$

Di antara murid-murid Ibnu Hazm adalah Muhammad bin Futuh bin Id yang memperdalan ilmu sejarah, Abu Abdillah al-Humaidi al- Andalusi yang mendalami dan mengajarkan buku-buku karya Ibnu Hazm sendiri. Kemudian putra-putra Ibnu Hazm, yaitu Abu Rafi' al-Fadl bin Ali,

\footnotetext{
${ }^{18}$ Hasbi al-Siddiqi, loc.cit.,

${ }^{19}$ Rahman Alwi,op.cit., h. 41-42

${ }^{20}$ Ibid., h. 42
} 
Abu Sulaiman al Musa'ab bin Ali, dan Abu

Usamah Ya'qub bin Ali. ${ }^{21}$

Bagi Ibnu Hazm ada suatu peristiwa yang sangat menyakitkan baginya, yaitu saat Spanyol terpecah-pecah menjadi beberapa negara kecil yang masing-masing dikepalai oleh Amir-amir Muluk Thawaif, seperti al- Mu'tadlid (berkuasa tahun 439$464 \mathrm{H}$ ) yang mencurigai Ibnu Hazm akan membahayakan kekuasaannya. alMu'tadlid bertindak tegas dengan membakar kitab-kitab karya Ibnu Hazm secara terang-terangan. ${ }^{22}$

Ibnu Hazm akhirnya kembali ke kampung halamannya di Manta Lisyam, di sana ia memusatkan perhatiannya kepada ilmu dan penulisan kitab- kitabnya kembali hingga ia wafat pada akhir Sya'ban tahun $456 \mathrm{H}$ dalam usia 71 tahun $^{24}$.

\section{Metode Penetapan Hukum Ibnu Hazm}

Ibnu Hazm mempunyai minhaj (metode) tersendiri dalam memahami nash yaitu minhaj Zhahiri yang jauh berbeda dengan mazhab yang ditempuh oleh jumhur. Dalam memahami suatu nash Ibnu Hazm mengambil langsung dari ketentuan nash al-Qur'an dan hadits, ia hanya melihat kepada zhahirnya saja. Tidak mentakwilkan hukum, tidak mencari-cari 'illat, bahkan ia mengatakan bahwa nash itu harus dipahami secara zhahirnya saja. ${ }^{23}$ berikut:

Sebagaimana beliau jelaskan sebagai

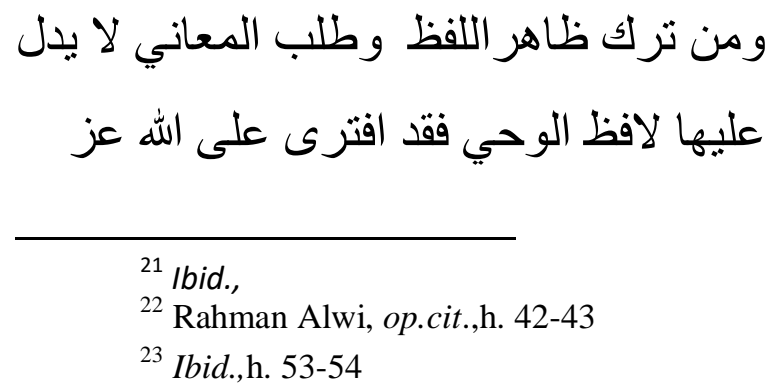

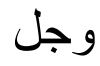

Barang siapa yang meniggalkan yang zhahirnya lafadzdan mencari-cari makna yang tidak ditunjuki oleh lafadz wahyu(yang zhahir), maka sesungguhnya dia telah mengadakan kebohongan terhadap Allah ,24

Adapun metode yang digunakan oleh Ibnu Hazm dalam melakukan istinbath hukum adalah sebagaimana yang dijelaskan dalam kitab al-Ihkam fii Ushul al-Ahkam:

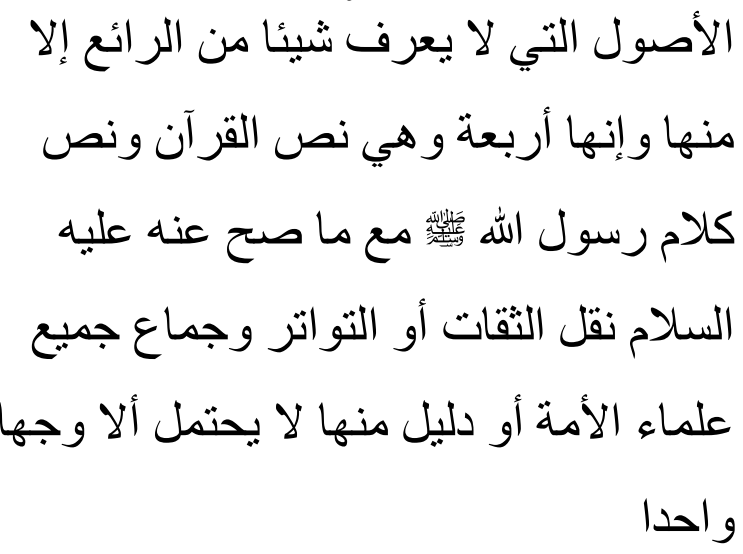

"Dasar-dasar hukum yang tidak diketahui sesuatu dari syara' melainkan dari pada dasar-dasar itu ada empat, yaitu: nash alQur'an, nash kalam rasulullah SAW yang sebenarnya datangnya dari Allah juga yang shahih kita terima dari padanya dan di nukilkan oleh orang-orang kepercayaan atau yang mutawatir dan yang di ijma'i oleh semua umat dan sesuatu dalil dari padanya yang tidak mungkin menerima selain dari pada suatu cara saja". 25

\section{Al-Quran}

Ibnu Hazm menetapkan bahwa al-

\footnotetext{
${ }^{24}$ Abu Muhammad Ali Bin Said Bin Hazm, al-Ihkam Fii Ushul al-Ahkam., op.cit, h. 239

${ }^{25}$ Ibid., h. 69
} 
Qur'an adalah kalamullah yang jelas dan nyata bagi umat. Maka barangsiapa yang berkehendak untuk mengetahui syari'atsyri'at Allah, dia akan menemukan terang dan nyata diterangkan oleh al-Qur'an sendiri, atau keterangan Nabi SAW. ${ }^{26}$

Ibnu Hazm mengatakan tidak ada didalam al-Qur'an yang mutasyabbih, yang tidak diberi penjelasan selain dua perkara saja, yaitu fawatihus suwar (huruf-huruf awal pembukaan surat) dan sunnatullah yang ada didalamnya. Selain dari urusan ini terang dan jelas maknanya bagi orang yang mengetahui ilmu bahasa secara mendalam dan mengetahui hadits-hadits yang shahih. $^{27}$

Ibnu Hazm berkata:

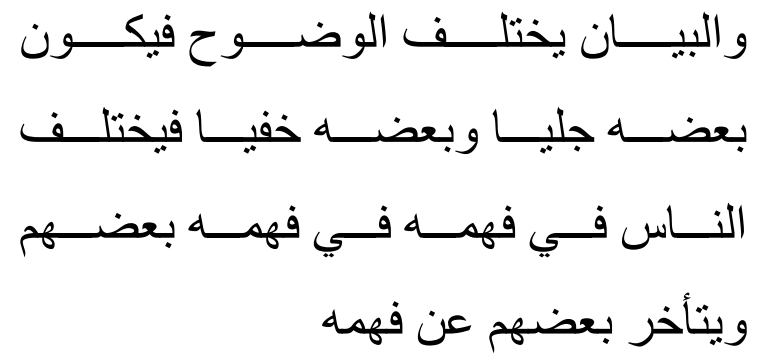

Bayan (penjelasan) berbeda-beda keduanya,sebagian jelas dan sebagian tidak jelas, karena itu manusia berbeda dalam memahaminya, sebagian mereka dapat mehami dan sebagian yang lain terlambat memahaminya,"28

Menurut Ibnu hazm bahwa dalam al-Qur'an dari sagi bayannya

terbagi kepada tiga bagian:

a. Jelas dengan sendirinya,tidak memerlukan bayan lagi baik dari alQur'an maupun hadits.

\footnotetext{
${ }^{26}$ Rahman Alwi, op.cit., h.74.

${ }^{27}$ Ibid.,

${ }^{28}$ Abu Muhammad Ali Bin Said Bin Hazm,
} al-Ihkam fii Ushul al-Ahkam, op.cit., h. 85 b. Mujmal,yang penjelasannya diterangkan oleh al-Qur'an sendiri.

c. Mujmal, yang di terangkan dalam hadits $^{34}$.

Berkenaan dengan hubungan nash yang satu dengan yang lainnya, Ibnu Hazm sangat memperhatikan adanya istisna' (pengkhususan dari lafal yang umum), nisakh(penguatan terhadap ketentuan sebelumnya), mansukh(penghapusan ketentuan sebelumnya), Dan ia melihat halhal tersebut sebagai bayan.

\section{Sunah}

Ibnu hazm memandang sunnah termasuk kedalam nash yang termasuk membina syari'at. Sunnah merupakan wahyu Allah, berdasarkan firman Allah SWT. dalam surat an-Najm: 3-4

"Dan tiadalah yang diucapnya itu (alQur'an) menurut kemauan hawa nafsunya. Ucapan itu tiada lain hanyalah wahyu yang diwahyukan (kepadanya) ${ }^{29}$

Menurut Ibnu Hazm, yang terjadi hujjah diantara tiga bagian sunnah (qaul,fi'il dan taqrir) hanyalah qaul (ucapan Nabi). Perbuatan-perbuatan Nabi tidak menunjukkan kepada wajib terkecuali bila dibarengi dengan ucapan atau ada qarinah (indikator) yang menunjukkan kepada wajib, atau perbuatan tersebut merupakan pelaksanaan dari perintah. ${ }^{30}$ Ibnu Hazm berkata:

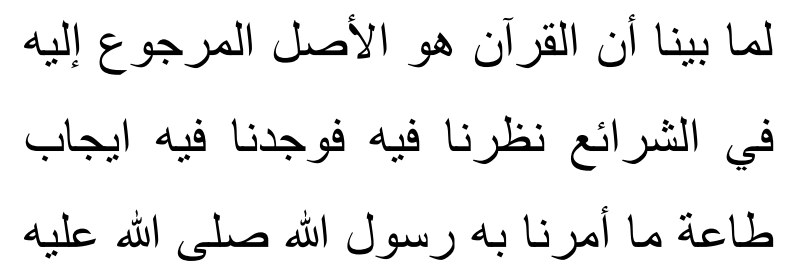

\footnotetext{
${ }^{29}$ Depertemen Agama RI, op.cit., h. 528

${ }^{30}$ Ibid., h. 75.
} 
وسلم ووجدناه عز وجل يقول فيه واصفا

لرسول الله ألا وحي يوحى) فصح بذلك أن الوحي ينقسم من الله عز وجل ألى رسول الله على قسمين أحدهما وهي متلو مؤلفا تأليفا معجز النظام وهو القرآن والثانى وحي مروي غير مؤلف ولا معجز النظام ولا متلو ولكنه مقروؤ وهو الخبر الوارد عن رسول اله

ketika kami telah menerangkannya bahwasanya al-Qur'an adalah pokok pangkal yang harus kepadaNya kita kembali dalam menentukan hukum, maka kami pun memperhatikan isinya. kalau kami mendapatkan di dalam keharusan mentaati apa yang Rasulullah menyuruh untuk kita kerjakan dan kami dapatkan Allah SWT menyatakan dalam al-Qur'an untuk mensifatkan kepada RasulNya (dan dia tiada menuturkan suatu dari hawa nafsunya kepadanya) bagi kami bahwasanya Wahyu dari Allah SWT terbagi menjadi dua. pertama, yang dibacakan yang merupakan mukjizat, yang kedua, wahyu yang diriwayatkan dari dan dinukilkan yang tidak disyariatkan untuk membacanya sebagai ibadah. Namun demikain itu tetap dibacakan dan itulah hadits Rasulullah SAW", ${ }^{1}$

Oleh karena itu Ibnu Hazm meletakkan sunnahnya sederajat dengan al-Qur'an dalam hal sebagai sumber syari'at maka ia menetapkan kepada dua dasar:

a. Sunnah dapat mentahksish alQur'an.

b. Takhsish dipandang sebagai bayan karena sunnah adalah bayan dari alQur'an.

\section{Ijma'}

Ibnu Hazm menempatkan ijma' sahabat sebagai sumber hukumnya yang ketiga setelah al-Qur'an dan hadits. Menurut Ibnu Hazm ijma' adalah sesuatu hal yang diyakini bahwa seluruh sahabat Rasulullah SAW.mengetahui masalah itu danmengatakannya, serta tidak ada seorang pun diantara mereka yang mengingkarinya. ${ }^{32}$

Secara logika Ibnu Hazm menyatakan bahwa para sahabat merupakan saksi mata yang sangat kuat berkaitannya dengan pengamalan nash baik dari al-Qur'an maupun dari hadits. Pergaulan Rasulullah SAW bersama para sahabat tidak lepas dari koreksi dan pengawasan langsung dari Allah SWT. ${ }^{33}$

Ibnu Hazm mengatakan sangat mustahil terjadi kekeliruan dalam pengamalan nash dimasa hidup mereka, sehingga perintah Allah SWT dan Rasulullah SAW pasti mereka patuhi. Begitu juga dengan apa yang mereka kerjakan lalu tidak ada teguran atau didiamkan oleh nash berarti disepakati tidak menyimpang dari nash. Sehingga dengan demikian ijma' sahabat pun pada prinsipnya tidak keluar dari jalur nash. ${ }^{34}$

\section{Al-Dalil}

${ }^{31}$ Abu Muhammad Ali Bin Said Bin Hazm, al-Ihkam Fi Ushul al-Ahkam, op.cit, h. 98 
Sumber hukum yang keempat Ibnu Hazm adalah al-dalil. Menurut teori al-dalil sama seperti ijma' sahabat, tidak keluar dari jalur nash. Al-dalil merupakan penetapan nash juga, hanya saja penggunaan teori ini sangat berkaitan erat dengan penguasaan ilmu mantiq (logika). ${ }^{35}$

Al-dalil menurut Ibnu Hazm tidaklah keluar dari nash maupun ijma', ia berbeda dengan qiyas, karena qiyas dasarnya adalah megeluarkan 'illatdari nash dan memberikan hukum kepada segala yang padanya terdapat illatitu. Sedangkan aldalil merupakan bagian dari nash itu sendiri. $^{36}$

Ibnu Hazm berpendapat bahwa semua ayat-ayat al-Qur'an dapat difahami isinya dengan jelas. Hanya saja, kekuatan akal manusia untuk memahami isi alQur'an itu berbeda-beda sehingga timbullah perselisihan dikalangan mereka. Ibnu Hazm berkeyakinan bahwa Rasulullah SAW telah menyampaikan agama Islam den menjelaskan secara utuh dan menyeluruh baik dari segi prinsip dasar (ushul) dan cabang-cabangnya (furu'), maupun sudut lahir dan batinnya, serta dari aspek teori (ilmu) dan prakteknya (amaliyah). ${ }^{37}$

Dengan demikian, bagi Ibnu Hazm wajib bagi umat Islam untuk melandasi pemahaman keagamaan mereka kepada dua sumber utama yaitu al-Qur'an dan hadits tanpa perlu melakukan ta'wil maupun ta'lil, hal ini menurutnya sangat penting demi menjaga kemurnian dan keaslian ajaran Islam. Orisinalitas ajaran Islam baik dibidang akidah, ibadah, muamalah, dan lainnya terletak kepada arti

\footnotetext{
${ }^{35}$ Ibid., h. 84.

${ }^{36}$ Ibid., h.

${ }^{37}$ Ibid., h. 44.
}

lahir (literal) yang terdapat dalam alQur'an dan hadits. ${ }^{38}$

Bagi Ibnu Hazm, tidak boleh ada ra'yu dalam masalah agama, barang siapa yang berijtihad dengan ra'yu maka berarti ia telah membuat kebohongan terhadap Allah SWT. Dengan demikian Ibnu Hazm menutup sama sekali pinti-pintu ijtihad $b i$ al-ra'yu seperti qiyas, istihsan, mashalihmursalah dan sad al-zara'i. ${ }^{39}$ Menurutnya al-Qur'an adalah kitab yang menerangkan segala sesuatu, maka tidak perlu bersusah payah mencari-cari 'illat dan maqasid itu memang jelas disebutkan oleh nash.

Berdasarkan penjelasan di atas mengenai pola penetapanhukum Ibnu Hazm, maka dapat diketahui bahwasanya intisari dari pemikiran Ibnu Hazm adalah menolak pendapat yang menyatakan bahwa penyembelihan hanya sampai pada harihari tasyriq saja sebagaimana pendapat mayoritas ulama pada masa itu. Pendapat tersebut didasarkan pada sebab-sebab berikut ini:

1. Landasan apa yang digunakan para ulama untuk menyatakan bahwasanya penyembelihan sampai hari tasriq saja.

2. Tidak adanya nash yang jelas mengatakan bahwa penyembelihan sampai hari tasyriq sebagaimana yang disebutkan oleh para ulama.

Sebagaimana telah dijelaskan di atas, pendapat Ibnu Hazm tersebut memiliki perbedaan dengan pendapat Imam mazhab. Di kalangan Imam mazhab, bahwa penyembelihan kurban itu sampai pada hari-hari tasyriq. Pada, kelompok mazhab

\footnotetext{
${ }^{38}$ Ibid., h. 47.

${ }^{39}$ Ibid., h. 64.
} 
Syafi'i, penyembelihan berakhir pada tanggal 13 Dzulhijjah. Sedangkan pendapat jumhur ulama yaitu Imam Abu Hanifah, Imam Malik, dan Imam Ahmadmengatakan penyembelihan adalah tiga hari yaitu pada hari raya haji dan dua hari setelahnya.

\section{Anggota Tubuh Terkhitbah yang Boleh Dipandang Menurut Para Ulama}

1. Mayoritas fuqaha' seperti Imam Malik, Asy-Syafi'i, dan Ahmad dalam salah satu pendapatnya mengatakan bahwa anggota tubuh wanita terkhitbah yang boleh dilihat hanyalah wajah dan kedua telapak tangan. $^{40}$

2. Ulama Hanbali berpendapat bahwa batas kebolehan memandang anggota tubuh wanita terpinang sebagaimana memandang wanita mahram, yaitu apa yang tampak pada wanita pada umumnya di saat bekerja di rumah, seperti wajah, kedua telapak tangan, leher, kepala, kedua tumit kaki, dan sesamanya. ${ }^{41}$

3. Ulama Hanafiyah dan Hanabilah yang masyhur mazhabnya berpendapat, kadar anggota tubuh yang diperbolehkan untuk dilihat adalah wajah, kedua telapak tangan dan kedua kaki, tidak lebih dari itu. ${ }^{42}$

\section{Anggota Tubuh Terkhitbah yang Boleh Dipandang Menurut Ibnu Hadzm adz Zahiri}

${ }^{40}$ Ibnu Rusyd, Bidayatul Mujtahid, jilid 2, h. 9.

${ }^{41}$ Abu Abdurrahman 'Adil bin Yusuf al'Azazi, Tamamul Minnah fi al-Kitab wa shohih asSunnah, jilid ke-3, (t.t.p, Darul Aqidah, .t.t.h), hal. 20

${ }^{42}$ Wahbah Az-zuhaili, Fiqh Islam Wa Adilatuhu, jilid 9, cet. 10, (Damaskus: darul fikr, $2007 \mathrm{M}-1428 \mathrm{H}$ ), hal. 34. $\begin{array}{cccr}\text { Ibnu Hazm } & \text { berpendapat } & \text { bahwa } \\ \text { saat melakukan } & \text { khitbah } & \text { seorang } \\ \text { laki-laki boleh } & \text { melihat } & \text { seluruh }\end{array}$ tubuh calon istrinya tanpa kecuali. Baik itu aurat ataupun bukan. Hal ini dapat dilihat ketika beliau menafsirkan Surat an- Nur, ayar 33:

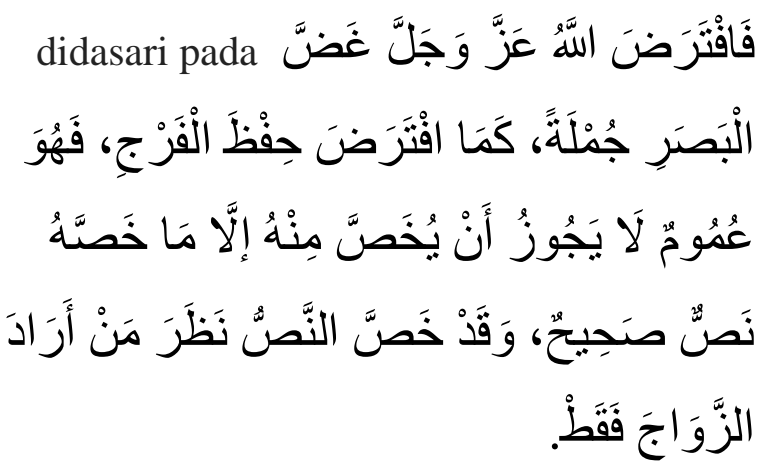

Allah Swt mewajibkan kepada kita untuk menjaga pandangan secara keselurahan, sebagaimana Allah Swt mewajibkan kepada kita untuk menjaga kemaluan.

Printah tersebut adalah perintah yang bersifat umum yang tidak dapat dikhususkan kecuali dengan nash yang berasal dari al Quran dan Sunnah yang Shahih, dan Allah telah mengjhususkan pandangan kepada lawan jenis bagi mreka yang ingin menikah (menikahi gadis yang ingin ia nikahi). ${ }^{43}$

Pendapat tersebut juga didasari oleh hadis hadis: "Jabir bin Abdillah:

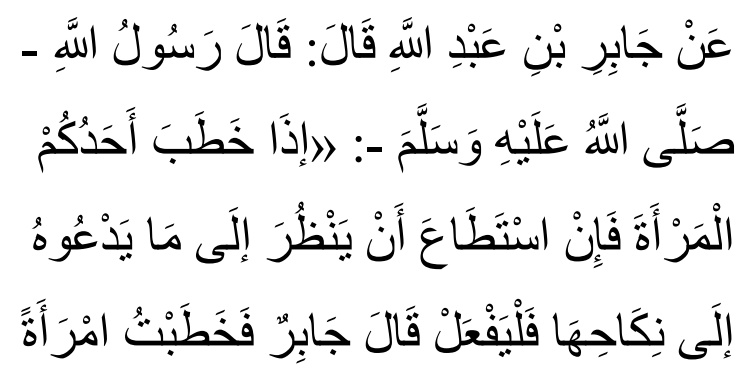

${ }^{43}$ Ibnu Hadzm adz Dzahiri, al- Muhalla bil atsar, dar elfikr, jilid. 9 , h. 161. 


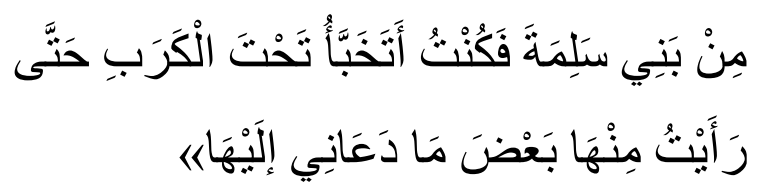

Dari Jabir bin Abdillah dia berkata, bahwa Rasulullah bersabda: apabila salah seorang di antara kamu melamar wanita, jika dia melihat suatu darinya yang menjadi daya tarik baginya untuk menikahinya, maka hendaklah dilakukannya, maka aku melamar seorang gadis. Kemudian Aku bersembunyi untuk memperlihatnya sehingga aku melihat sesuatu padanya hal yang menarikku menikahinya dan mengawininya." (HR. Imam Abu Dawud, Hakim dan Baihaqi) ${ }^{44}$

\section{Penutup}

Ibnu Hazm mempunyai minhaj (metode) tersendiri dalam memahami nash yaitu minhaj Zhahiri yang jauh berbeda dengan mazhab yang ditempuh oleh jumhur. Dalam memahami suatu nash Ibnu Hazm mengambil langsung dari ketentuan nash alQur'an dan hadits, ia hanya melihat kepada zhahirnya saja. Tidak mentakwilkan hukum, tidak mencari-cari 'illat, bahkan ia mengatakan bahwa nash itu harus dipahami secara zhahirnya saja. Ibnu Hazm menetapkan bahwa al-Qur'an adalah kalamullah yang jelas dan nyata bagi umat. Maka barangsiapa yang berkehendak untuk mengetahui syari'at-syri'at Allah, dia akan menemukan terang dan nyata diterangkan oleh al-Qur'an sendiri, atau keterangan Nabi SAW.

Ibnu Hazm mengatakan tidak ada didalam al-Qur'an yang mutasyabbih, yang tidak diberi penjelasan selain dua perkara saja, yaitu fawatihus suwar (huruf-huruf awal pembukaan surat) dan sunnatullah yang ada didalamnya. Selain dari urusan ini terang dan jelas maknanya bagi orang yang mengetahui ilmu bahasa secara mendalam dan mengetahui hadits-hadits yang shahih.

Pada permasalahan anggota tubuh terkhitbah yang boleh dipandang, Ibnu Hadzm adz Zahiri mengambil muthlak teks Hadis yang diriwayatkan oleh Jabir. Menurut beliau surat an - Nur ayat 33 dikhususkan oleh hadis yang diriwayatkan jabir, dari yang tadinya dilarang menjadi halal untuk dilihat.

\section{Daftar Pustaka}

Abu Abdurrahman 'Adil bin Yusuf al'Azazi, Tamamul Minnah fi alKitab wa shohih as-Sunnah, jilid ke-3, (t.t.p, Darul Aqidah, .t.t.h)

Ahmad bin Muhammad bin Muhammad bin Hambal, Musnad Ahmad bin Hambal, dar elfikr, cetakan pertama; 2011

Ahmad Kuseri, Nikah Sebagai Perikatan, Jakarta: Raja Grafindo Persada, 1995

Dewan Redaksi Ensiklopedia Islam, Ensiklopedia Islam, (Jakarta: Ichtiar Baru Van Hoeve, 1994)

Hasbi al-Siddiqi, Pokok-pokok Pegangan Imam-imam Mazhab dalam Membina Hukum Islam, (Jakarta: Bulan Bintang, 1974)

Ibnu Hadzm adz Dzahiri, al- Muhalla bil atsar, Dar el - Fikr

Ibnu Rusyd, Bidayatul Mujtahid, jilid 2, (t,t,p, al-Qowaaniinu al-Fiqhiyah, t.th)

Rahman Alwi, Metode Ijtihad Mazhab al-Zahiri Alternatif Menyongsong Modernitas, (Jakarta: Gaung 
Persada Press, 2005)

Wahbah Az-zuhaili, Fiqh Islam Wa

Adilatuhu, jilid 9, cet. 10,

(Damaskus: darul fikr, $2007 \mathrm{M}$ $1428 \mathrm{H})$ 